\title{
ポリグリセリン脂肪酸エステルの水ー油系での相挙動と キュービック相で姿定化された乳化ゲル生成
}

\author{
國枝 博信*1・荒牧 賢治*2・西村 貴幸*1・石飛 雅彦*3 \\ * 1 横浜国立大学大学院工学研究科人工環境システム学専攻（テ240-8501 神奈川県横浜市保土ケ谷区常盤台 79-5) \\ * 2 横浜国立大学工学部物質工学科（テ 240-8501＼cjkstart神奈川県横浜市保土ケ谷区常盤台 79-5） \\ $* 3$ 三菱化学株式会社横浜総合研究所機能化学研究所（厂227-8502 神奈川県横浜市青葉区鴨志田町 1000)
}

\section{Phase Behavior of Polyglycerin Fatty Acid Ester in a Water-Oil System and Formulations of Gel-Emulsions Stabilized by the Cubic Phase}

\author{
Hironobu KUniedA ${ }^{* 1}$, Kenji ARAMAKI ${ }^{* 2}$, Takayuki Nishimura ${ }^{* 1}$ \\ and Masahiko IsHitoBI ${ }^{* 3}$ \\ * 1 Division of Artificial Environment and Systems, Graduate School of Engineering, Yokohama National University \\ (Tokiwadai 79-5, Hodogaya-ku, Yokohama-shi, Kanagawa-ken 240-8501) \\ * 2 Division of Material Science and Chemical Engineering, Faculty of Engineering, Yokohama National University \\ (Tokiwadai 79-5, Hodogaya-ku, Yokohama-shi, Kanagawa-ken 240-8501) \\ * 3 Specialty Chemicals Laboratory, Yokohama Research Center, Mitsubishi Chemical Corporation \\ (Kamoshida-cho 1000, Aoba-ku, Yokohama-shi, Kanagawa-ken 227-8502)
}

\begin{abstract}
Examination was made of the phase behavior of polyglycerin fatty acid esters in a water-oil system and aggregate structure by phase study and amall angle X-ray scattering (SAXS). Polyglycerin laurate $\left(10 \mathrm{G}^{*} 0.7 \mathrm{~L}\right.$ and $\left.20 \mathrm{G}^{*} 1 \mathrm{~L}\right)$ were used, $10 \mathrm{G}^{*}$ and $20 \mathrm{G}^{*}$ indicating the average polymerization degree of polyglyceryl chain as 10 and 20 , respectively. Neither 10 $\mathrm{G}^{*} 0.7 \mathrm{~L}$ nor $20 \mathrm{G}^{*} 1 \mathrm{~L}$ formed a cubic phase in water at $25^{\circ} \mathrm{C}$ but did so with the addition of a trace amount of decane. The cubic phase was found to be a discontinuous micellar cubic phase $\left(\mathrm{I}_{1}\right)$ with a face or body centered cubic lattice by SAXS. Micelles in $\mathrm{I}_{1}$ were not completely spherical. The thermal stability of $I_{1}$ was improved with increase in the solubilization of decane. Maximum solubilization of $\mathrm{m}$-xylene and squalane in $\mathrm{I}_{1}$ was studied and greater solubilization of m-xylene and less solubilization of squalane compared to decane were noted. An excess oil phase was found to coexist with $I_{1}$ beyond the solubilization limit of $I_{1}$ and the oil phase could be dispersed in $\mathrm{I}_{1}$ as emulsion droplets. The highly viscous and stable gel emulsion with oil content of $80 \%$ could be formulated.
\end{abstract}

Key words : polyglycerin fatty acid ester, phase behavior, cubic phase, gel emulsion, small angle $\mathrm{x}$-ray scattering

\section{1 緒言}

ポリグリセリン脂肪酸エステルは親水基であるポリグ リセリン鎖の重合度，結合脂肪酸数・種類を変化させる ことにより，親水性一親油性バランス（HLB）を様々に コントロールすることができる非イオン界面活性剤であ る。また耐酸性, 耐塩性, 耐加水分解性に比較的に優れ

連絡者：國枝博信
ているだけでなく，食品添加物として認可されており， 安全性が高いことから食品·化粧品用の乳化・可溶化· 改質牏として広く用いられている。しかし，実際に用い られているポリグリセリン脂肪酸エステルはエステル化 度，ポリグリセリン鎖の鎖長分布等の異なる種々の誘導 体の混合物であり，また，未反応のポリグリセリンを多 量に含んでいるため, その溶液の基礎的な研究は極めて 少ない1)。䉆谷ら ${ }^{2)}$ は重合度の低い, 極めて高純度のポ リグリセリンアルキルエーテルを用いて，その水-油へ 
の相挙動を研究し, 通常のポリオキシエチレン型非イオ ン界面活性剤と比較して可溶化力が極めて大きいことを 見いだしている。また，グリセリン基 1 個がオキシエチ レン基 3 個分の親水性に相当すると報告している。しか し，よく用いられる重合度の大きいものについては，市 販品を用いた研究はあるが，これらには通常，多量の未 反応ポリエーテルが含まれており，これが相挙動及び自 己組織体形成に大きく影響することが既に指摘されてい $3^{3), 4)}$ 。

乳化の安定性を高めるためには界面エネルギーを下 げ，細かい乳化滴を生成したり，乳化滴の合一速度を遅 くする必要がある。前者の熱力学的手法は界面活性能の 高い界面活性剤の選択が重要になるが，実用的には合一 速度を遅くすることが安定な乳化を得る必須条件であ る。合一を防ぐには分散滴に電荷を持たせ静電的反発力 を増すこと, 高分子などで乳化滴を覆って立体的反発力 を増すこと，また溶媒の粘性を高めて合一及び凝集の頻 度因子を下げることなどが行われている。近年, 化粧品 用クリームの安定化に高粘性でかつ, 構造が熱エネル ギーに対して安定であるリオトロピック液晶の利用が試 みられている。ラメラ液晶による $\mathrm{O} / \mathrm{W}$ 型乳化 ${ }^{5)}$, 逆へ キサゴナル液晶による $W / O$ 乳化の安定化 ${ }^{6)}$ 等が報告さ れているが, 本研究室で最近, キュービック相 (discontinuous micellar cubic phase, $\mathrm{I}_{1}$ 相) を利用し た，90\% 以上の油含有率を持つ $\mathrm{O} / \mathrm{W}$ 型高内相比乳化 (HIPRE) の調製を報告した7)。この $\mathrm{I}_{1}$ 相は球状ミセ ルもしくは球形に近いミセルが面心立方あるいは体心立 方格子に充填した光学的に等方性の高粘度液晶である。 $I_{1}$ 相により安定化された乳化 (cubic-phase based emulsion）の特徴の第一は $\mathrm{I}_{1}$ 相は他の液晶相と比較し て非常に高粘性であるため, 得られる乳化物も非常に高 粘性であること，また第二に $\mathrm{I}_{1}$ 相中の界面活性剤の濃 度が高いため，その屈折率は比較的高く，油の屈折率と 同程度にでき，透明な乳化物が得られることである。さ らに界面活性剤の親水性がある程度強ければ, 界面活性 剤の HLB の微妙な制御が必要ないことも特徴としてあ げられる。

通常, $I_{1}$ 相は非常に親水性の強い界面活性剤系におい てのみ形成される。例えばポリオキシエチレンアルキル エーテル系の場合, エチレンオキシドの重合度が 8 以上 のドデシルエーテル, ヘキサデシルエーテル8), 10 以上 のオレイルエーテル99 など，また非イオンのショ糖オク タン酸エステル及びデカン酸エステル10)，イオン性の DTAC (Dodecyltrimethylammonium chloride) ${ }^{11)}$ 等であ る。ゆえに長鎖のポリグリセリン脂肪酸エステル系にお いても $I_{1}$ 相の形成が期待できる。

本論文では精製された鎖長分布の狭い長鎖のポリグリ セリン脂肪酸エステルの水十油中での溶解挙動を調べ,
形成された $\mathrm{I}_{1}$ 相によって安定化した乳化ゲルを生成さ せることができたので報告する。

\section{2 実験}

\section{$2 \cdot 1$ 試薬}

阪本薬品工業社製のポリグリセリン＃ 500，\# 750 (水 酸基価により求めた平均重合度はそれぞれ 5.9，10.9) を疑似移動床型クロマト分離装置 ${ }^{12}$ ) (三菱化学エンジニ アリング (株) 製，カラム： $2450 \mathrm{ml} \times 4$ 本，使用樹脂 : ポリスチレンージビニルベンゼンゲルを母体とする強 酸性カチオン交換樹脂 UBK-530（三菱化学製， $\mathrm{Na}^{+}$型， 平均粒径 230-240 mm，交換容量 $1.6 \mathrm{meq} / \mathrm{ml}$ ）を用いて 溶離水を脱塩水, カラム温度を $60^{\circ} \mathrm{C}$, 流速 $60 \mathrm{ml} / \mathrm{min}$ として分画し，高重合度側の成分として，平均重合度 10.65，21.3の分布の狭いポリグリセリンを得た。Fig. 1 に分画前後のそれぞれのクロマトグラムを示す。クロ マトグラム中の数字はポリグリセリンの重合度を表す。

これらの分布の狭いポリグリセリンと日本油脂（株）

製のラウリン酸（純度 99\%）に，10\% 水酸化ナトリウ ム水溶液を水酸化ナトリウムの全量に対する割合が $0.0025 \mathrm{wt} \%$ になるように加え，窒素気流下，常圧で $240^{\circ} \mathrm{C}, 2.5$ 時間反応させた後, $260^{\circ} \mathrm{C}$ に昇温して，さ らに 4 時間反応させてエステル化させた。収率は仕込み のポリグリセリンで反応したポリグリセリンを除して 100 倍したものとして Table 1 にまとめた。多量の未反 応ポリグリセリンの除去を次の方法により行った。イソ ブチルアルコール (IBA) へ反応生成物を溶解させ, $15 \%$ $\mathrm{Na}_{2} \mathrm{SO}_{4}$ 水溶液との混合液を $70^{\circ} \mathrm{C}$ で 30 分間攪拌し，水 相側に未反応ポリグリセリン，油相側にポリグリセリン エステルを抽出した。油相を分離し，そこへ，さらに， $15 \% \mathrm{Na}_{2} \mathrm{SO}_{4}$ 水溶液 $700 \mathrm{ml}$ を加え，同様の操作をした。 分離した油相から，IBAをエバポレーターにより留去 し，粗ポリグリセリン脂肪酸エステルを得た。また残存 $\mathrm{Na}_{2} \mathrm{SO}_{4}$ を除くためにエタノール溶液から再結晶させ た。以上の操作をもって最終的に未反応ポリグリセリン 含有量が約 $2 \%$ のポリグリセリンラウリン酸エステル を得た。得られたポリグリセリンラウリン酸エステルを Table 1 に示す。平均結合脂肪酸数は仕込みラウリン酸 モル数を反応ポリグリセリンモル数で除して求めた。名 称の $10 \mathrm{G}^{*}, 20 \mathrm{G}^{*}$ はおよそのポリグリセリンの平均重 合度を示し， $0.7 \mathrm{~L} ， 1 \mathrm{~L}$ はラウリン酸のポリグリセリ ンに対する仕込のモル比を表わす。

n-デカン，スクアラン， $\mathrm{m}^{-キ}$ キレンは東京化成工業 株式会社の特級品を用いた。水はイオン交換水を蒸留し て用いた。

\section{$2 \cdot 2$ 相平衡図の作製}

所定の試薬をアンプルチューブに入れ，熔封した。挸 拌混合し, 恒温相中で静置し，平衡状態を観察した。へ 
(a) Polyglycerine \#500 Average Polymerization Degree $=5.9$

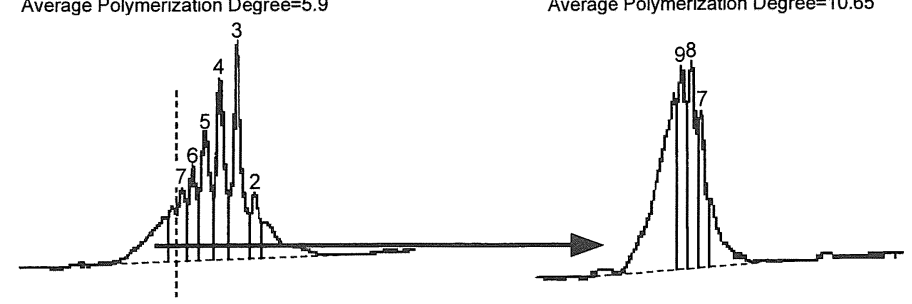

(c) Polyglycerine \#750

Average Polymerization Degree $=10.9$

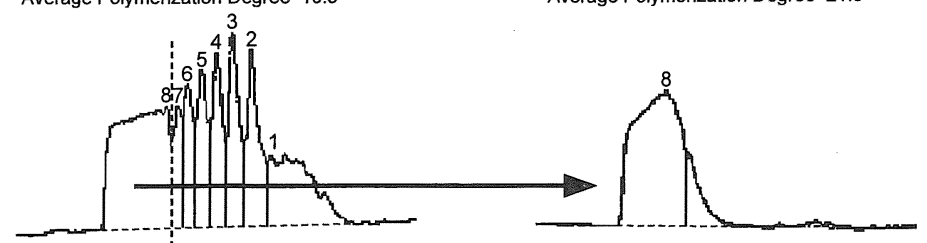

(b) $10 G^{*}$

Average Polymerization Degree $=10.65$

Fig. 1 Chromatograms of Polyglycerines. (a) and (c) are for commercial grade products. (b) and (d) are for polyglycerines with relatively narrow distribution of polymerization degree which is separated at the dotted line in (a) and (c) by pseudo-moving bed chromatography. Numbers in the chromatograms indicate the polymerization degree of polyglycerine.

Table 1 Polyglycerine Fatty Acid Esters

\begin{tabular}{|l|c|c|}
\hline Product Name & $10 \mathrm{G}^{*} 0.7 \mathrm{~L}$ & $20 \mathrm{G}^{*} 1 \mathrm{~L}$ \\
\hline Yield (\%) & 31.4 & 53.1 \\
\hline Unreacted Polyglyceryl Residue after Purification(\%) & 2.04 & 2.10 \\
\hline Average Number of Fatty Acid per Polyglyceryl Chain & 2.23 & 1.88 \\
\hline Average Polymerization Degree of Polyglyceryl Chain & 10.65 & 21.3 \\
\hline
\end{tabular}

キサゴナル液晶は直行ニコル下での観察，偏光顕微鏡， 小角 X 線散乱（SAXS）により確認した。キュービッ ク相は著しい高粘性及び光学的等方性, SAXSにより 確認した。

\section{$2 \cdot 3$ SAXS 測定}

回転対陰極 X 線回折装置（リガク製 RINT-2500, $\mathrm{CuK} \alpha, 18 \mathrm{~kW})$ により行った。試料をポリエチレンテ レフタラートフィルムで包むマイラーシール法を用い た。液晶の構造は散乱強度ピークから得られる面間隔の 比から同定した。へキサゴナル液晶, 面心立方格子また は体心立方格子のキュービック液晶に対応する面間隔比 はそれぞれ $1: 1 / \sqrt{3}: 1 / 2,1: 1 / \sqrt{2}: 1 / \sqrt{3}$ である。

\section{$2 \cdot 4$ 界面活性剂のモル体積}

$10 \mathrm{G}^{*} 0.7 \mathrm{~L}$ およびその親水基であるポリグリセリン (平均重合度 $10.65,10 \mathrm{G}^{*}$ ) のメタノール及びエタノー ル溶液の密度を Anton Paar 社製デジタル密度計 DMA 40 で $25^{\circ} \mathrm{C}$ において測定した。溶液の濃度と密度の逆数 をプロットし，溶媒 $0 \%$ に補外し，それぞれの物質の 液体状態の密度とした ${ }^{9)} 。 10 \mathrm{G}^{*} 0.7 \mathrm{~L}, 10 \mathrm{G}^{*}$ の密度は それぞれ $1.20,1.34 \mathrm{~g} \cdot \mathrm{cm}^{-3}$ と得られた。またTable 1 の值から平均の分子量を求めるとそれぞれ，1215，807 $\mathrm{g} \cdot \mathrm{mol}^{-1}$ となり，密度と分子量よりモル体積はそれぞれ $1.01 \times 10^{3}, 6.02 \times 10^{2} \mathrm{~cm}^{3} \cdot \mathrm{mol}^{-1}$ と求まる。 $10 \mathrm{G}^{*} 0.7 \mathrm{~L}$ の場合, ポリグリセリン鎖 1 本当りの平均エステル化度 
(結合脂肪酸数) は 2.23 であるので疎水鎖（0.7 L）の モル体積は $\left(1.01 \times 10^{3}-6.02 \times 10^{2}\right) / 2.23=183 \mathrm{~cm}^{3}$. $\mathrm{mol}^{-1}$ となる。

\section{3 結果と考察}

$3 \cdot 1$ 水/ポリグリセリンラウリルエステル/デカン系 の相挙動

Fig. 2 に $25^{\circ} \mathrm{C}$ に打ける $10 \mathrm{G}^{*} 0.7 \mathrm{~L}\left(20 \mathrm{G}^{*} 1 \mathrm{~L}\right) /$ 水/デ カン 3 成分系の相平衡図を示す。

水 $-10 \mathrm{G}^{*} 0.7 \mathrm{~L}$ 軸，すなおち，2成分系においては界 面活性剂濃度 $70 \mathrm{wt} \%$ 付近までミセル水溶液相 $\left(\mathrm{W}_{\mathrm{m}}\right)$ が存在し，それより高濃度側にへキサゴナル液晶 $\left(\mathrm{H}_{1}\right)$ が形成される。この 2 成分系においては出現する液晶は

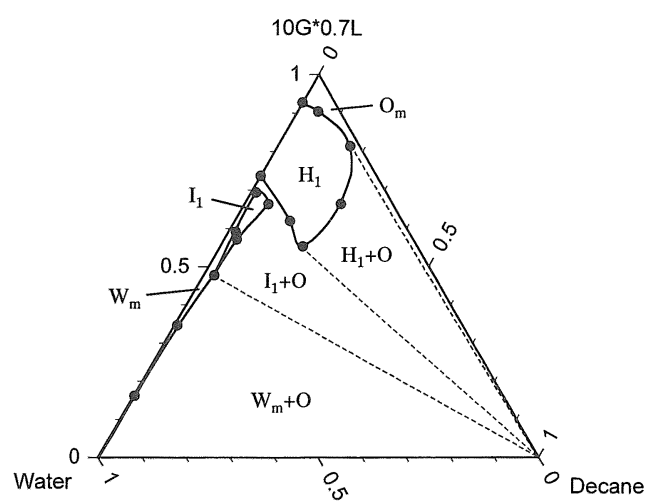

Fig. 2 (a) Phase Diagram in Water $/ 10 \mathrm{G}^{*} 0.7 \mathrm{~L} /$ Decane System at $25^{\circ} \mathrm{C}$. $\mathrm{W}_{\mathrm{m}}, \mathrm{H}_{1}, \mathrm{I}_{1}, \mathrm{O}_{\mathrm{m}}$ and $\mathrm{O}$ indicate an aqueous micellar phase, a hexagonal liquid crystalline phase, a discrete micellar cubic phase, a reverse micellar phase and an excess oil phase, respectively.

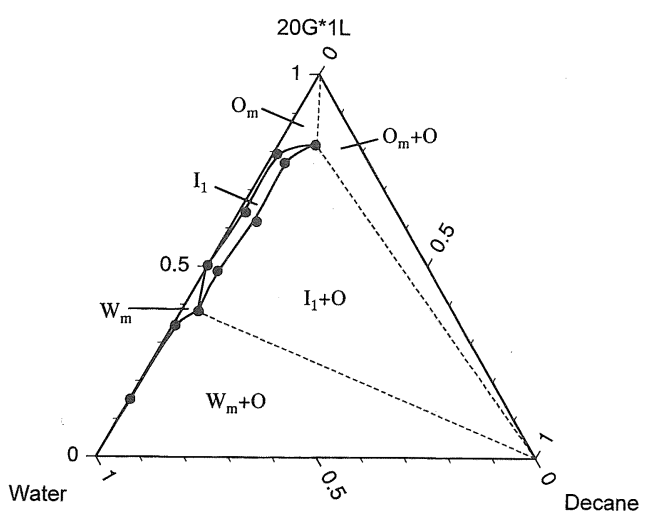

Fig. 2 (b) Phase Diagram in Water $/ 20 \mathrm{G}^{*} 1 \mathrm{~L} /$ Decane Systems at $25^{\circ} \mathrm{C}$. Phase notations are same as Fig.2(a).
$\mathrm{H}_{1}$ 相のみであり， $25^{\circ} \mathrm{C}$ より低温でも光学的に等方性で あり，高粘性のキュービック相は観測されなかった。水 $-20 \mathrm{G}^{*} 1 \mathrm{~L}$ 軸では界面活性剤濃度 $60 \mathrm{wt} \%$ 付近で, $20^{\circ} \mathrm{C}$

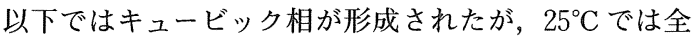
濃度領域に渡って等方性水溶液であった。つまり両系に おいて，水一界面活性剛 2 成分系で $25^{\circ} \mathrm{C}$ ではキュービッ ク相は存在しない。

しかし，少量のデカンが可溶化されると，両系とも $I_{1}$ 相が形成される。つまり，油の可溶化によりキュービッ ク相の形成が著しく促進されることが分かる。キュー ビック相は大きく分けて，4 種類が知られている。すな わち，ミセルが立方晶に充填した discontinuous micellar cubic 相 $\left(I_{1}\right)$ ，水も界面活性剂集合体も連続した構 造を持ち，界面活性剂分子層の曲率がやや正である normal bicontinuous cubic 相 $\left(\mathrm{V}_{1}\right), \mathrm{V}_{1}$ と同様の構造で あるが，界面活性剤分子層の曲率がやや負である reverse bicontinuous cubic 相 $\left(\mathrm{V}_{2}\right)$ および, 球状の逆ミ セルが立方晶に充填した discontinuous reverse micellar cubic 相 $\left(\mathrm{I}_{2}\right)$ である。ここで界面活性剤分子層の曲率 は水に対して凸の場合を正，凹の場合を負とする。それ ぞれのキュービック相はさらに，構造の微妙な相違によ り，サブグループに分けられる。このうち， $\mathrm{I}_{1}$ 相は相平 衡図上の $\mathrm{W}_{\mathrm{m}}$ 相と $\mathrm{H}_{1}$ 相との間， $\mathrm{V}_{1}$ 相は $\mathrm{H}_{1}$ 相と $\mathrm{L}_{\alpha}$ 相 との間に存在することが知られている。また， $V_{2}$ 相は $\mathrm{L}_{\alpha}$ 相と逆へキサゴナル液晶 $\left(\mathrm{H}_{2}\right)$ 相との間, $\mathrm{I}_{2}$ 相は $\mathrm{H}_{2}$ 相と逆ミセル油溶液相との間に存在することも知られて いる。ただし， $\mathrm{I}_{2}$ 相は両親媒性高分子 ${ }^{13)}$ ，糖系 ${ }^{14)}$ ・シリ コーン系の界面活性剤 ${ }^{15)}$ の一部などで形成されることが 知られているのみで，一般の合成界面活性剤系ではあま り形成されない。Fig. 2a のキュービック相は $\mathrm{H}_{1}$ と $\mathrm{W}_{\mathrm{m}}$ の間に形成されていることから，ミセルが立方晶に充填 した $\mathrm{I}_{1}$ 相であると考えられる。このように，水一界面活 性剂 2 成分系ではキュービック相が存在せず，油添加に より形成される例はポリオキシエチレン型の非イオン界 面活性剂系でも知られている ${ }^{16)}$

油をより加えるといずれの系も過剩の油相が相分離す る。従って，各相と油相の tie line は全てデカン頂点へ 向かっている。 $\mathrm{I}_{1}$ 相と $\mathrm{I}_{1}+\mathrm{O}$ との境界を目視で求めるの は困難である。それは $I_{1}$ 相と過剩の油相の屈折率差が 小さいため，油相がわずかに分離する状態では 1 相と誤 認するからである。 $I_{1}$ 相に油を可溶化すると Fig. 3に 示すように，SAXS 測定から得られる面間隔が増大す る。これは油が可溶化されることにより，ミセルが大き くなり，会合数が増加するため，ミセルの数が減少する からである。可溶化限界に達すると面間隔は一定になる。 この SAXS 測定により，Fig. 2 の $I_{1}$ 相の可溶化限界を 決定した。 


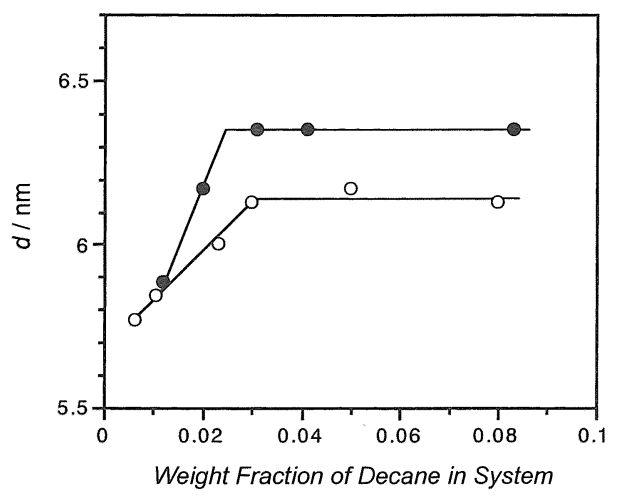

Fig. 3 The Change in Interlayer Spacing, $d$, of $\mathrm{I}_{1}$ Phase as a Function of Decane Content at $25^{\circ} \mathrm{C}$ in Water $/ 10 \mathrm{G}^{*} 0.7 \mathrm{~L} /$ Decane (filled circle) and Water $/ 20 \mathrm{G}^{*} 1 \mathrm{~L} /$ Decane (open circle) Systems.

\section{$3 \cdot 2$ SAXS 測定}

$\mathrm{I}_{1}$ 相を SAXS により測定して得られるスペクトルの 例を Fig. 4 に示す。

散乱ピーク (Fig. 40矢印) から得られる面間隔比が $1: 1 / \sqrt{2}: 1 / \sqrt{3}$ となっており，ミセルが面心立方格子 または体心立方格子に配列した $\mathrm{I}_{1}$ 相であることが確認 できる。

水/界面活性剤比を $1 / 1$ に固定して $\mathrm{n}$-デカン, $\mathrm{m}$-キシ レン，スクアランを添加していった場合の $d$ 值を SAXS により測定し，その結果を Fig. 5a に示す。

Fig. 3 の場合と同様に可溶化限界を超えると $d$ 值が一 定になる。球状ミセルが立方晶に配列した幾何学的なモ デルを考えると, ミセルの疎水部の半径 $r_{I}$, 親水性一疎

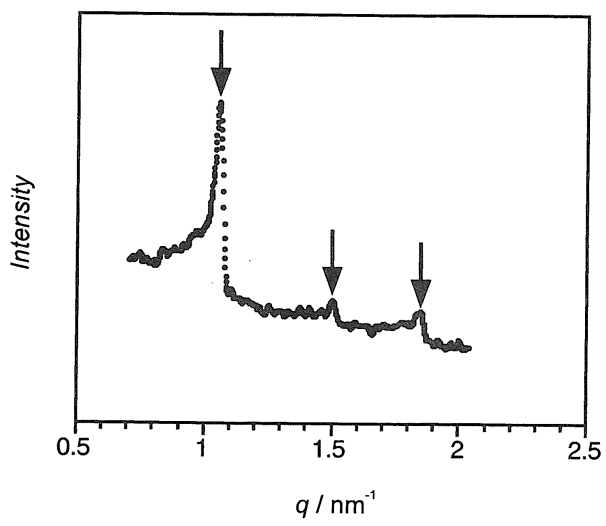

Fig. 4 A typical SAXS Spectrum of $I_{1}$ Phase at $25^{\circ} \mathrm{C}$ in the Water $10 \mathrm{G}^{*} 0.7 \mathrm{~L} /$ Squalane System. The composition is water $/ 10 \mathrm{G}^{*} 0.7 \mathrm{~L} /$ squalane = 45/45/10 (weight ratio).
水性界面における疎水鎖 1 本当りの有効断面積 $a_{S}$ は次 のように表せる。

$$
\begin{aligned}
& r_{I}=d \cdot\left(\frac{3}{4 \pi} \frac{\left(\phi_{L}+\phi_{O}\right)}{n_{c}}\right)^{1 / 3} \cdot C \\
& a_{S}=\frac{3 v_{L}}{r_{I}} \frac{\phi_{L}+\phi_{O}}{\phi_{L}}
\end{aligned}
$$

ここで $\phi_{L} ， \phi_{O}$ はそれぞれ界面活性剤疎水部, 油の系 中の体積分率, $n_{C}$ は単位立方格子中の球状ミセルの個 数であり，面心立方格子，体心立方格子の場合それぞれ 4, 2 である。C $C$ 定数で面心立方格子, 体心立方格子 の場合それぞれ $\sqrt{3}, \sqrt{2}$ である。得られた $d$ 值より面 心立方，体心立方格子それぞれの $r_{I} ， a_{S}$ を求めた結果 をFigs. 5b, c にプロットした。 $r_{I}$ はすべての油につい て油の添加量とともに増加し，ミセルが油の可溶化によ り大きくなっていることを示す。また $a_{s}$ はデカン，ス クアランの添加によってはあまり変化しないが， $\mathrm{m}$-キ シレンの場合は大きく増加している。これは $\mathrm{m}$-キシレ ンがミセルのパリセード層（柵層）へ可溶化される傾向 が強いこと成)を映している。

液体状態の炭化水素鎖の有効断面積は約 $0.22 \mathrm{~nm}^{2}$ 17) であるので前述の $10 \mathrm{G}^{*} 0.7 \mathrm{~L}$ の疎水鎖 1 本のモル体積 $\left(183 \mathrm{~cm}^{3} \cdot \mathrm{mol}^{-1}\right)$ から疎水鎖の伸びきり鎖長を概算す ると約 $1.4 \mathrm{~nm}$ となる。Fig. $5 \mathrm{~b} の r_{I}$ は油の最も少ない 時であっても約 $2.2 \mathrm{~nm}$ であり，疎水鎖の伸びきり鎖長 よりもかなり長くなっている。これは球状ミセルが配列 したモデルで計算したためであり，他の親水性の強いポ

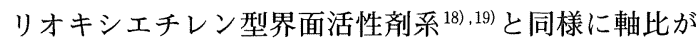
1 を越える，非対称なミセルが配列していることを示唆 している。

\section{$3 \cdot 3$ 油添加効果}

$10 \mathrm{G}^{*} 0.7 \mathrm{~L}$ の $50 \%$ 水溶液にデカンを加えたときの相 挙動を Fig. 6 に示す。

ここでも少量のデカンの添加により $\mathrm{I}_{1}$ が形成される ことが確認できる。 $I_{1}$ 相の熱安定性は可溶化量の増加と ともに急激に增している。ポリオキシエチレン型界面活 性剂 $\left(\mathrm{C}_{12} \mathrm{EO}_{25}\right)$ 系においても同様の熱安定性の増加が 観察されている7 が，油の可溶化により球状ミセルの軸 比が 1 に近くなり，結果としてミセルの立方格子への パッキングが完全になるためと予想されている。このよ うな棒状ミセルから球状ミセルへの油の可溶化による転 移はミセル水溶液中に打いても報告されている20)。この 棒状ミセル $\left(\mathrm{H}_{1}\right.$ 相） から球状ミセル $\left(\mathrm{I}_{1}\right.$ 相 $)$ への転移 はミセル表面積を増加させないで蹯水部の体積が増加す るために起こると考えられる。 $\mathrm{I}_{1}$ 相にさらにデカンを添 加すると可溶化限界を超える $\left(\mathrm{I}_{1}+\mathrm{O}\right)$ 。

$\mathrm{I}_{1}$ 相の融解温度に対するポリグリセリン鎖長の影響を 調べるためにFig. 7 に示すようにポリグリセリンエス テルー油比を固定して水の濃度を変えた相図を作成した。 


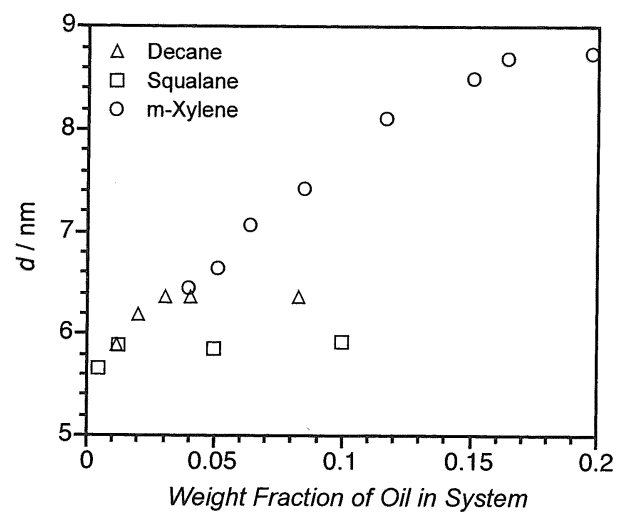

Fig. 5 (a) The Change in the Interlayer Spacing, $d$, as a Function of Weight Fraction of Oil in the Water/10 G*0.7 L/Oil Systems.

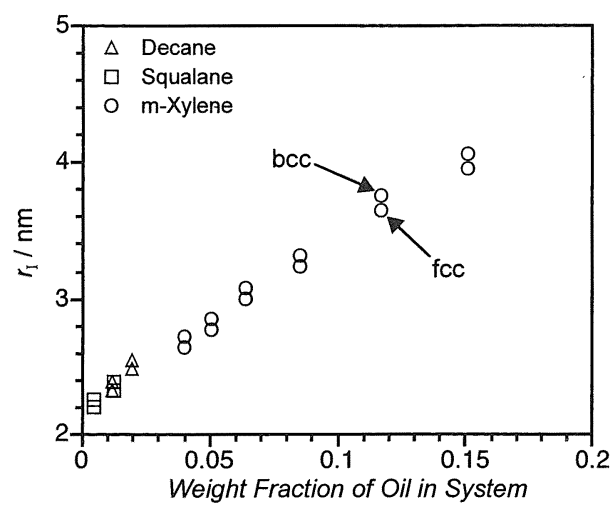

Fig. 5 (b) The Change in the Radius of Micelles in $I_{1}$ Phase, $r_{I}$, as a Function of Weight Fraction of Oil in the Water/ $10 \mathrm{G}^{*} 0.7 \mathrm{~L} / \mathrm{Oil}$ Systems. Higher and lower values in the same system are calculated from body-centered cubic (bcc) and face-centered cubic (fcc) model, respectively.

$10 \mathrm{G}^{*} 0.7 \mathrm{~L}$ 系より $20 \mathrm{G}^{*} 1 \mathrm{~L}$ 系において $\mathrm{I}_{1}$ 相の最高融 点が高くなっており, 油を添加しない場合 ${ }^{21)}$ と同じ傾向 である。

$3 \cdot 4$ キュービック液晶の融点に対する油の種類の効 果

Fig. 8 は $50 \% 10 \mathrm{G}^{*} 0.7 \mathrm{~L}$ 水溶液へ種々の油を添加し たときの $\mathrm{I}_{1}$ 相の融解温度の変化を調べたものである。

$\mathrm{m}$-キシレンを用いた場合が融解温度が最も高く, ス クアランの場合が最も低くなっている。Fig. 5a の $d$ 値 の変化に示すように，この系のデカンを添加した場合の $25^{\circ} \mathrm{C}$ に打ける可溶化限界は系に対する油の濃度が約 $2.7 \%$ である。また同様にスクアランを添加した場合は 可溶化限界は少なく, $\mathrm{m}$-キシレンを添加した場合はか

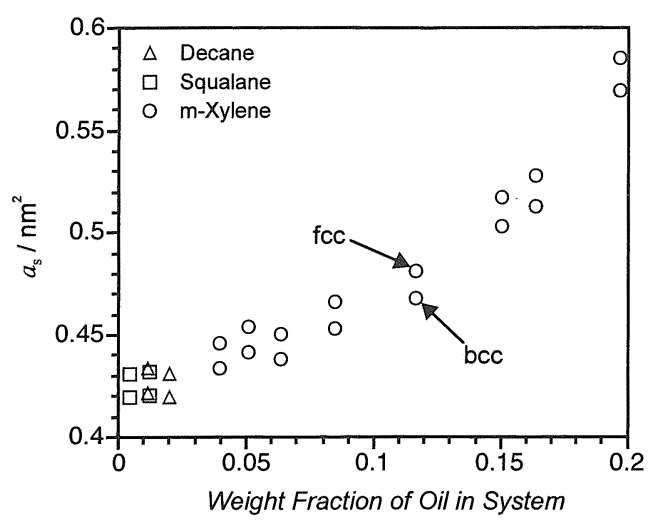

Fig. 5 (c) The Change in the Effective Cross Sectional Area per Surfactant Lipophilic Chain at the Interface, $a_{s}$, as a Function of Weight Fraction of Oil in the Water/10 $\mathrm{G}^{*} 0.7 \mathrm{~L} / \mathrm{Oil}$ Systems. Higher and lower values in the same system are calculated from face-centered cubic (fcc) and body-centered cubic (bcc) model, respectively.

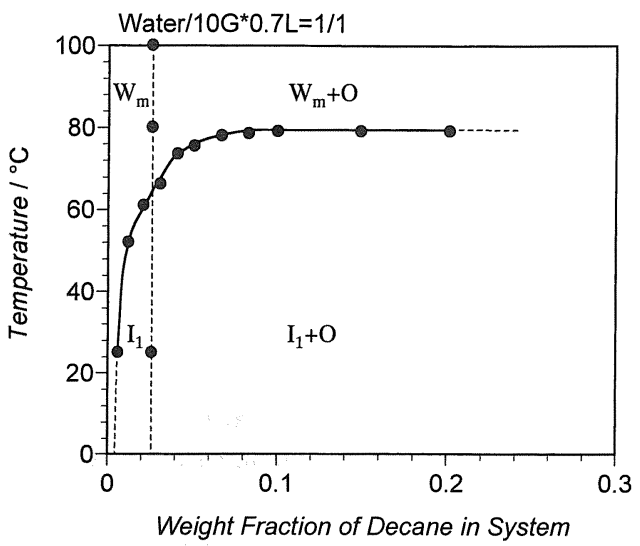

Fig. 6 The Effect of Added Decane on the Phase Behavior in Water $/ 10 \mathrm{G}^{*} 0.7 \mathrm{~L}$ System. The water $/ 10 \mathrm{G}^{*} 0.7 \mathrm{~L}$ ratio is $1 / 1 . \mathrm{I}_{1}+\mathrm{O}, \mathrm{W}_{\mathrm{m}}+\mathrm{O}$ indicate the two phase of $\mathrm{I}_{1}$ and excess oil, $\mathrm{W}_{\mathrm{m}}$ and excess oil, respectively.

なり多くなっている。Fig. 8 に示すように油を可溶化す ることにより $\mathrm{I}_{1}$ 相の融解温度は上昇し, その程度は可 溶化量が増えると増加しているので, 最大可溶化量の大 小が $\mathrm{I}_{1}$ 相の最高融解温度の高低に関係していると考え られる。また，一般に分子量の小さい油は親水性一親油 性界面近傍（パリセード層）に多く可溶化され，分子量 の大きな油は自己組織体内部により多く可溶化され，こ こで用いた油に関しては $\mathrm{m}$-キシレン, デカン，スクア ランの順にパリセード層への可溶化が多い16)。Fig. 5c の $a_{s}$ の変化からも本系においても上記の傾向があるこ 


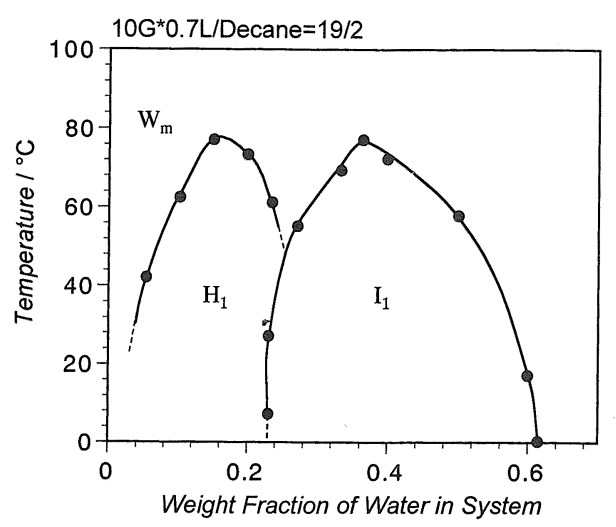

Fig. 7 (a) The Phase Diagram in the Water $/ 10 \mathrm{G}^{*} 0.7$ L/Decane System as a Function of Weight Fraction of Water in the System. The surfactant/decane ratio is kept at 19/2.

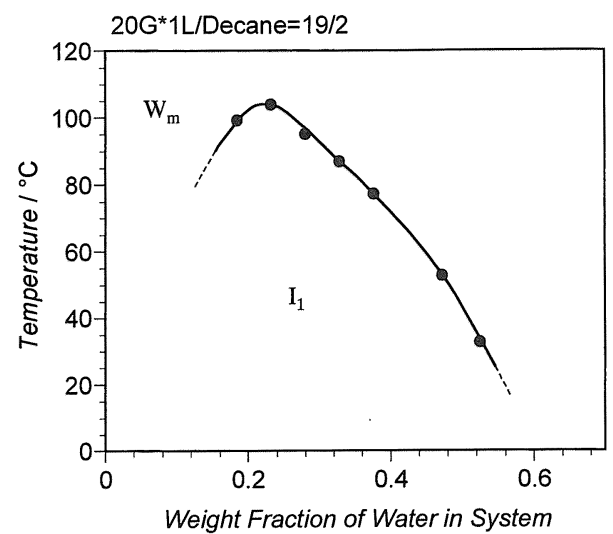

Fig. 7 (b) The Phase Diagram in the Water $/ 20 \mathrm{G}^{*} 1$ L/Decane System as a Function of Weight Fraction of Water in the System. The surfactant/decane ratio is kept at 19/2.

とは明らかである。このパリセード層への可溶化量が大 きいほど会合体の界面活性剤膜をより負の曲率の方向へ 変化させる ${ }^{16)}$ 。故により大きなミセル，つまり，より多 いミセルへの可溶化が $\mathrm{m}$-キシレンを用いた場合に可能 になっていると考えられる。

\section{5 キュービック液晶を連続相とした乳化ゲル}

Fig. $2 \mathrm{~b}$ に示すように $\mathrm{I}_{1}$ 相中への可溶化量は少なく, 過剩の油相が分離する 2 相になる。この 2 相領域のサン プルを $\mathrm{I}_{1}$ 相の融解温度（約 $80^{\circ} \mathrm{C}$, Fig. 6 参照）以上に すると可溶化ミセル水溶液相 $\left(\mathrm{W}_{\mathrm{m}}\right)$ と油相の 2 相にな り，擋拌により水中油滴分散 $(\mathrm{O} / \mathrm{W})$ 型の乳化を得る ことができる。この乳化を再び常温へ急冷すると $\mathrm{I}_{1}$ 相 中に油滴を分散させることができる。この乳化は $\mathrm{I}_{1}$ 相

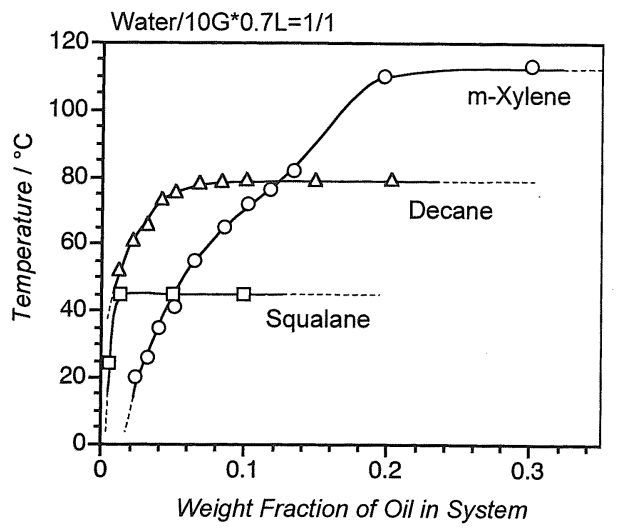

Fig. 8 The Change in Melting Temperature of $\mathrm{I}_{1}$ Phase in Water $/ 10 \mathrm{G}^{*} 0.7 \mathrm{~L} / \mathrm{Oil}$ Systems. The water/surfactant ratio is kept $1 / 1$.

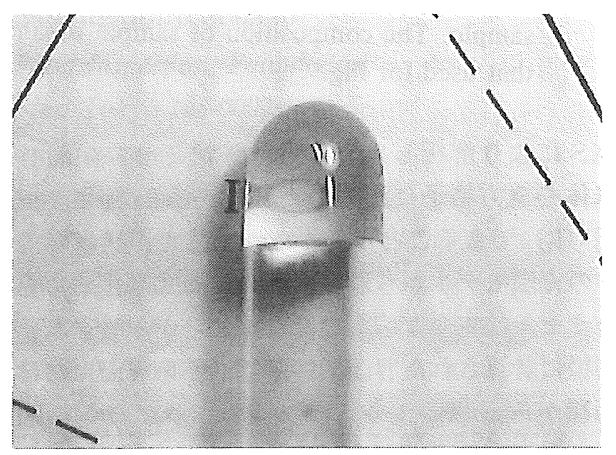

Fig. 9 A photograph of Cubic-phase Based Emulsion Formed in the Water $/ 10 \mathrm{G}^{*} 0.7 \mathrm{~L} /$ Decane System. The composition is water $/ 10 \mathrm{G}^{*} 0.7$ $\mathrm{L} /$ decane $=1 / 1 / 8$ (weight ratio). Note the transparency of the gel.

が連続相となっているため, 非常に高粘性, 安定である。 また $\mathrm{I}_{1}$ 相の屈折率は比較的高く ${ }^{7)}$, 界面活性剤濃度を調 節することによりデカンと屈折率を等しくすることがで き, Fig. 9 (水 $/ 20 \mathrm{G}^{*} 1 \mathrm{~L} /$ デカン=1/1/8) のような透明 な乳化ゲルも得ることができる。

これを顕微鏡観察すると Fig. 10のようにミクロン オーダーの油滴が最密充填率を越えて多角形になって充 填していることが分かり，いわゆる乳化ゲル22)になって いることが分かる。

\section{4 総括}

ポリグリセリンの平均重合度が 10,20 のラウリン酸 エステル $\left(10 \mathrm{G}^{*} 0.7 \mathrm{~L}, 20 \mathrm{G}^{*} 1 \mathrm{~L}\right)$ は両方とも水の中で はキュービック相を形成しないが，わずかなデカン， m-キシレン, スクアランの添加によりキュービック相 が形成されることが分かった。このキュービック相を 


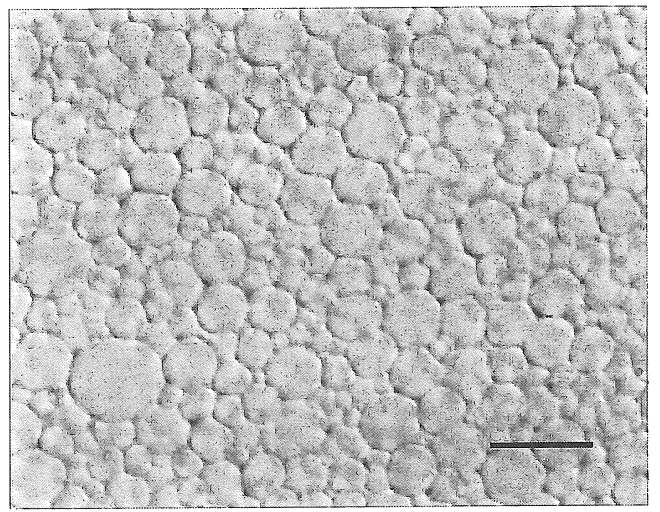

Fig. 10 A microscopic Photograph of the Cubic-phase Based Emulsion Observed by Differential Interference Contrast Microscope. The bar is 50 $\mu \mathrm{m}$. To increase the contrast, a trace amount of water-soluble dye is incorporated in the sample. The composition of sample is same as that used for Fig.9.

SAXS により解析したところ, 球状ミセルが面心ある いは体心立方格子に配列した discontinuous キュービッ ク相 $\left(\mathrm{I}_{1}\right)$ であることがわかった。また，幾何学的なミ セルの充填モデルから計算されたミセル半径から充填さ れたミセルは完全な球形ではないことが示唆された。ま た同様に計算された界面活性剤親油基の界面における占 有面積から m-キシレン，デカン，スクアランの順にパ リセード層への可溶化が減少することが示唆された。 $\mathrm{I}_{1}$ への油の可溶化量が増すこと, 油のパリセード層への可 溶化が増すこと，また，長鎖のポリグリセリン鎖のもの を用いることにより $\mathrm{I}_{1}$ の融解温度は上昇することが分 かった。 $\mathrm{I}_{1}$ へのデカンの可溶化限界を超えると $\mathrm{I}_{1}$ が過 剰の油相と共存する 2 相になる。このとき, 温度を $\mathrm{I}_{1}$ の融解温度以上に上げ，十分に擋拌した後，冷却すると $\mathrm{I}_{1}$ 相中に油を分散させることが可能であり, 油の割合が $80 \%$ に達する極めて高粘性かつ安定なゲルを形成する ことに成功した。このゲルはミクロンオーダーの油滴が 最密充填率を越えて詰まっている，いわゆる乳化ゲルで あることが分かった。

(受付： 2000 年 1 月 11 日, 受理：2000 年 2 月 16 日)

\section{文献}

1) W. Hemker, J. Am. Oil Chem. Soc., 58, 114 (1981).

2) H. Sagitani, Y. Hayashi, M. Ochiai, J. Am. Oil Chem. Soc., 66, 146 (1989).

3) T. Iwanaga, M. Suzuki, H. Kunieda, Langmuir, 14, 5775 (1998).

4) 金 峰, 荒牧賢治, 柳原孝次, 國枝博信, 日本油 化学会誌，47, 1233 (1998).

5) 中間康成, 塩島義浩, 春澤文則, 日本油化学会誌, 47, 585 (1998).

6) 中間康成, 塩島義浩, 春澤文則, 日本油化学会誌, 47, 1331 (1998).

7) C. Rodriguez, K. Shigeta, H. Kunieda, J. Colloid Interface Sci., 223, 197 (2000).

8) D.J. Mitchell, G.J.T. Tiddy, L. Waring, T. Bostock, M.P. McDonald, J. Chem. Soc. Faraday Trans. 1, 79, 975 (1983).

9) H. Kunieda, K. Shigeta, K. Ozawa, M. Suzuki, $J$. Phys. Chem. B, 101, 7952 (1997).

10) 兼井典子, 今栄東洋子, 鬼原 薰, 田川 徹, 國 枝博信，日本油化学会誌，45, 849 (1996).

11) R.R. Balmbra, J.S. Clunie, J.F. Goodman, Nature, 222, 1159 (1969).

12) 佐藤康平, 化学装置, 3 月号, 56 (1996).

13) P. Alexandridis, U. Olsson, B. Lindman, Langmuir, 12, 1419 (1996).

14) H. Minamikawa, M. Hato, Langmuir, 14, 4503 (1998).

15) 堀井真紀子, 國枝博信, 原島朝雄, 第 38 回油化学 討論会講演要旨集 (名古屋市), p.108 (1999).

16) H. Kunieda, K. Ozawa, K.-L. Huang, J. Phys. Chem. B, 102, 831 (1998).

17) A.W. Adamson, Physical Chemistry of Surfaces, 5th ed., Wiley, New York (1990) p.133.

18) D. Danino, Y. Talmon, R. Zana, J. Colloid Interface Sci., 186, 170 (1997).

19) B. Håkansson, P. Hansson, O. Regev, O. Soderman, Langmuir, 14, 5730 (1998).

20) H. Hoffmann, W. Ulbricht, J. Colloid Interface Sci., 129, 388 (1989).

21) M. Ishitobi, H. Kunieda, Colloid Polym. Sci., submitted., "Effect of Distribution of Hydrophilic Chain on the Phase Behavior of Polyglycerol Fatty Acid Ester in Water".

22) H. Kunieda, D.F. Evans, C. Solans, M. Yoshida, Colloid Surf., 47, 35 (1990). 
[報文］より高度の不飽和脂肪酸メチルエステル由来の ペルオキシルラジカルはミセル中心から界面へ
移動してミセル水溶液中での高度不飽和脂質の
酸化反応性を低下させる

矢津一正 ${ }^{* 1}$ 。山本順寛 ${ }^{* 2}$-二 二木鋭 雄 ${ }^{* 2}$ 三木 啓司*1 ・ 請川 孝 治*1

*1 資源環境技術総合研究所（テ 305-8569 茨城県つくば市小野川 16-3）

*2 東京大学先端科学技術センター（† 153-8904 東京都目黒区駒場 4-6-1）

高度不飽和脂肪酸であるドコサヘキサエン酸，エイコサペンタエン酸，アラキドン酸， $\alpha$-リノレン酸， $\gamma-$

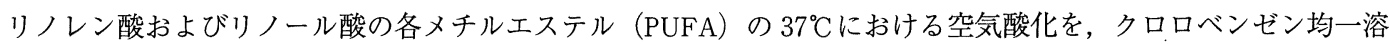
液中および Triton X-100 ミセル水溶液中で行った。PUFA の酸化による基質減少速度は, 均一系溶液中では不 飽和度の増加にともない増加したが，ミセル中では逆に減少した。酸素吸収量と基質減少量の比が不飽和度の増 加にともない 1 から 3.4 まで増加したことから, ドコサヘキサエン酸メチルやエイコサペンタエン酸メチルなど のより高度の不飽和脂肪酸メチルエステル由来のペルオキシルラジカルは, リノール酸メチル由来のペルオキシ ルラジカルに比べより極性が強いと考えられる。ミセル水溶液中でのリノール酸メチルと他の PUFA の $1 ： 1$ 混合基質の酸化で，PUFA とリノール酸メチルの酸化速度の比は不飽和度の増加にともない増加するのにも関 わらず，基質減少速度の和は逆に減少したことから，より高度の不飽和脂肪酸メチルエステル由来のペルオキシ ルラジカルは連鎖反応の進行にほとんど関与しないことが示唆された。ミセル中心に存在することのわかってい るブチルヒドロキシトルエンの PUFA の酸化に伴う減少速度は，不飽和度の増加にともない減少した。以上の デー夕は, より高度不飽和脂肪酸メチルエステル由来のペルオキシルラジカルはミセル中心から界面へ移動し, これにより連鎖停止反応が促進され，また連鎖成長反応が抑制されるため高度不飽和脂肪酸の酸化速度が減少す るという考えを支持する。

（連絡者：山本順寛） Vol.49, No.6, 611（2000）

\section{[報文］ポリグリセリン脂肪酸エステルの水 - 油系での相挙動 とキュービック相で安定化された乳化ゲル生成}

國枝博信*1 。荒牧賢治*2。西村貴幸*1 。石 飛 雅 彦*3

$* 1 \quad$ 横浜国立大学大学院工学研究科人工環境システム学専攻

（率 240-8501＼cjkstart神奈川県横浜市保土ヶ谷区常盤台 79-5）

*2＼cjkstart横浜国立大学工学部物質工学科（广 240-8501 神奈川県横浜市保土ヶ谷区常盤台 79-5)

*3 三菱化学株式会社横浜総合研究所機能化学研究所（广 227-8502 神奈川県横浜市青葉区鴨志田町 1000)

未反応ポリグリセリンを除いたポリグリセリン脂肪酸エステルの水 - 油中での相挙動を調べ, 自己組織体構造 を小角 X 線散乱法（SAXS）により調べた。ポリグリセリンの平均重合度が 10，20 のラウリン酸エステル

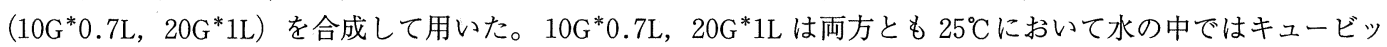
ク相を形成しないが,わずかなデカンの添加によりキュービック相が形成されることが分かった。このキュービッ ク相をSAXSにより解析したところ，球状ミセルが面心あるいは体心立方格子に配列した discontinuous キュー ビック相 $\left(\mathrm{I}_{1}\right)$ であることがわかり，充填しているミセルは完全に球状ではないことが示唆された。デカンの可溶 化量の増加とともに $\mathrm{I}_{1}$ の熱安定性は良くなる。 $\mathrm{m}$ - キシレン, スクアランの $\mathrm{I}_{1}$ への可溶化量を調べた結果, 前者 はデカンより多く，後者はデカンより少ない。 $\mathrm{I}_{1}$ へのデカンの可溶化限界を超えると $\mathrm{I}_{1}$ が過剩の油相と共存す る 2 相になる。このとき， $\mathrm{I}_{1}$ 相中に油を乳化滴として分散させることが可能であり，油の割合が $80 \%$ に達する 極めて高粘性かつ安定な乳化ゲルを形成することに成功した。

（連絡者：國枝博信） Vol.49，No.6，617（2000） 